\section{God informasjon om matallergier}

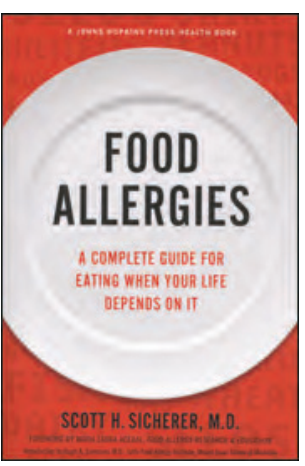

Scott H. Sicherer

Food allergies

A complete guide for eating when your

life depends on it. 304 s, ill. Baltimore,

MD: The Johns Hopkins University Press,

2013. Pris USD 16

ISBN 978-1-4214-0845-3

Målgruppen er først og fremst personer med matallergi og foreldre til barn som har matallergi, men boken kan med fordel benyttes av leger og annet helsepersonell som får spørsmål relatert til matallergier. Den er blitt til som et resultat av de mange spørsmål forfatteren er blitt stilt i et langt yrkesliv som pediater. Hans hovedarbeidsog interessefelt er allergiske sykdommer, spesielt matallergier.

Boken er oversiktlig bygd opp med 11 kapitler med blant annet grunnleggende fakta om matallergier, hvordan søke råd og hjelp i helsevesenet, hvilke sykdommer som kan ha sin bakgrunn i matallergi, og hvordan leve med matallergi. Spørsmål og svar er enkelt formulert og lett forståelig selv uten medisinsk bakgrunnskunnskap. Forfatteren legger ikke skjul på hvor problematisk, og i enkelte tilfeller livstruende, en matallergi kan være, uten å overdramatisere.

Forfatteren befinner seg i front når det gjelder forskning på området og redegjør greit for den nyeste kunnskapen vedrørende utredning og behandling, hva som er kunnskapsmangler, og tester og behandling som den etablerte medisinen ikke kan stå inne for. Han legger ikke fingrene imellom når det gjelder å advare mot useriøse aktører, men gir en kort beskrivelse av ikke anbefalte tester og behandlinger slik at leseren får et innblikk i hva disse innebærer. Når det gjelder medisinsk utredning, er de amerikanske og europeiske anbefalingene relativt like, slik at boken lett kan benyttes på norske forhold.

Matallergi kan føre til straksallergiske symptomer, men også til mer protraherte eller kroniske plager. Forfatteren går igjennom de forskjellige uttrykkene ved en matallergi samtidig som han legger vekt på mulighetene for differensialdiagnoser. Han anbefaler ikke egendiagnoser, men gir råd om hvordan ta opp en mistanke om allergi med primærlegen.

I løpet av de siste 10-15 årene er det skjedd en gradvis forandring i veiledningen til gravide når det gjelder forebygging av allergier. Fra å anbefale gravide med høy risiko for å få barn med allergi til å unngå allergener som egg og fisk i svangerskapet og ammeperioden, gis det nå råd om vanlig kost uten restriksjoner til alle. Hvordan et slikt skifte kan skje, redegjør han godt for.

Dette er en bok som er nyttig lesing for pasienter og pårørende, men som også kan være en svært lærerik oppslagsbok for fastleger og annet helsepersonell. En norsk oversettelse vil være en fordel.

\section{Ragnhild Halvorsen}

Spesialist i immunologi og transfusjonsmedisin Oslo

\section{Litt haltende om nevrorehabilitering}

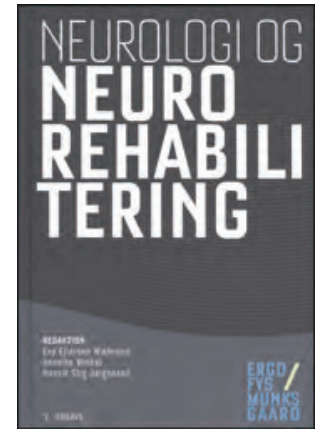

Eva Ejlersen Wæhrens, Annette Winkel, Henrik Stig Jørgensen, red. Neurologi og neurorehabilitering 2. utg. 519 s, tab, ill. København: Munksgaard Danmark, 2013. Pris DKK 575

ISBN 978-87-628-1016-7

Dette er annen utgave av det danske verket, som primært er beregnet på fysioterapeuter og ergoterapeuter som arbeider med nevrorehabilitering $\mathrm{i}$ hverdagen. Leger og sykepleiere som arbeider innenfor disse feltene, også ved sykehjem, vil kunne ha glede av boken. Den er delt i fire: Den generelle delen er en god og rask innføring i nevroanatomi og generell symptomlære, f.eks. spastisitet og blæreforstyrrelser. I den andre delen tar forfatterne for seg de viktigste nevrologiske sykdommene, mens del tre omhandler rehabilitering av disse. I del fire presenterer de fysio- og ergoterapeutisk teori, inkludert bevegelsesvitenskap. Forfatterne er en rekke danske spesialister med bakgrunn fra fysioterapi, ergoterapi, nevrologi, nevrospykiatri og psykologi.

Del en og to er det lite å utsette på. Fra en leges ståsted er imidlertid del tre den viktigste delen, ettersom nevroanatomi og sykdomslære omtales i mange andre læreverk. Del tre omfatter om lag 110 sider og er dessverre den svakeste og mest overfladiske. Dette reflekterer muligens at effekten av rehabiliteringstiltak ved vanlige nontraumatiske nevrologiske sykdommer i mange tilfeller er dårlig dokumentert. Om dette skyldes at det er vanskelig å utføre gode studier innen feltet, eller om rehabiliteringstiltakene har begrenset effekt, gir boken i liten grad svar på.

Teksten er like fullt preget av stor vilje til vitenskapelighet og akademisering, med hyppige referanser til studier som sjelden er avklarende. Dette går muligens på bekostning av formidling av forfatternes konkrete kliniske erfaring, for eksempel av hvordan rehabiliteringsarbeidet utføres i praksis. Det gjør at jeg sitter igjen med relativt få nyttige innspill.

Utvalget av litteratur kan i noen tilfeller virke litt søkt og utdatert: En Cochrane-rapport om kognitiv rehabilitering ved demens fra 2003 drøftes i detalj, spesielt at det ikke hadde vært utført randomiserte kliniske studier. La gå at boken muligens gikk i trykken før en tilsvarende Cochrane-rapport ble publisert i 2013, der nettopp en randomisert klinisk studie omtales, men det forsvarer ikke at man dveler ved ti år gamle oversiktsartikler og metaanalyser. Det gir også et dårlig inntrykk at korrekturlesingen av og til svikter, for eksempel har nummereringen av halve referanselisten falt ut i MS-kapitlet. En mer alvorlig svakhet er at boken ikke omfatter ryggmargsskade, som er et meget viktig felt innen nevrorehabiliteringen.

Til tross for sine svakheter representerer denne utgivelsen et verdifullt initiativ. Nevrologiske sykdommer og skader er hyppige og har store konsekvenser både for den enkelte og for samfunnet. Boken illustrerer at akademisering i seg selv ikke nødvendigvis løfter fagfeltet til ønsket nivå.

Trygve Holmøy

Professor, Nevroklinikken

Akershus universitetssykehus 